\title{
Feedstock Modification for Enhanced Additive Alloys
}
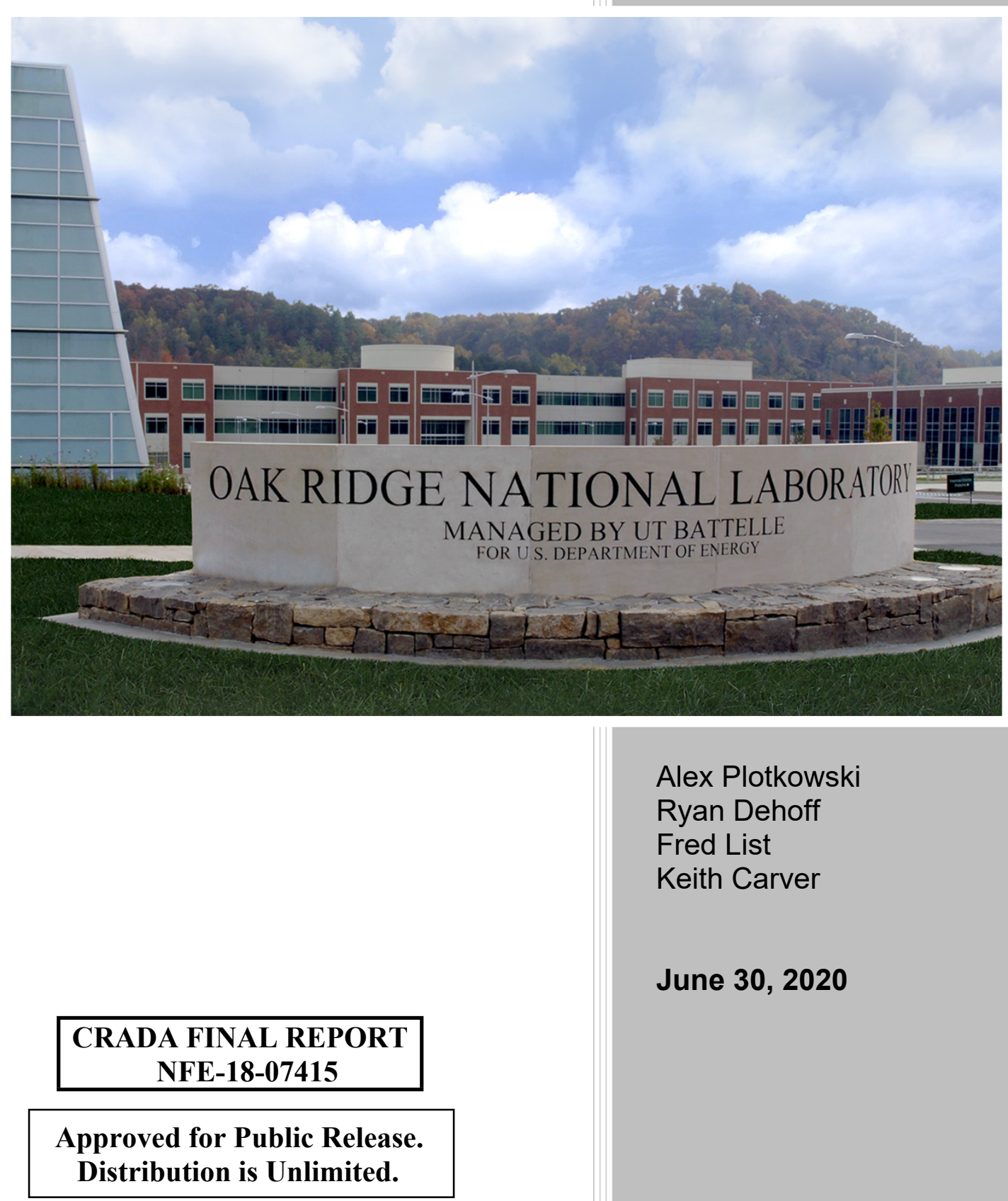

Alex Plotkowski

Ryan Dehoff

Fred List

Keith Carver

June 30, 2020 


\title{
DOCUMENT AVAILABILITY
}

Reports produced after January 1, 1996, are generally available free via US Department of Energy (DOE) SciTech Connect.

Website www.osti.gov

Reports produced before January 1, 1996, may be purchased by members of the public from the following source:

\author{
National Technical Information Service \\ 5285 Port Royal Road \\ Springfield, VA 22161 \\ Telephone 703-605-6000 (1-800-553-6847) \\ TDD 703-487-4639 \\ Fax 703-605-6900 \\ E-mail info@ntis.gov \\ Website http://classic.ntis.gov/
}

Reports are available to DOE employees, DOE contractors, Energy Technology Data Exchange representatives, and International Nuclear Information System representatives from the following source:

Office of Scientific and Technical Information

PO Box 62

Oak Ridge, TN 37831

Telephone 865-576-8401

Fax 865-576-5728

E-mail reports@osti.gov

Website http://www.osti.gov/contact.html

\begin{abstract}
This report was prepared as an account of work sponsored by an agency of the United States Government. Neither the United States Government nor any agency thereof, nor any of their employees, makes any warranty, express or implied, or assumes any legal liability or responsibility for the accuracy, completeness, or usefulness of any information, apparatus, product, or process disclosed, or represents that its use would not infringe privately owned rights. Reference herein to any specific commercial product, process, or service by trade name, trademark, manufacturer, or otherwise, does not necessarily constitute or imply its endorsement, recommendation, or favoring by the United States Government or any agency thereof. The views and opinions of authors expressed herein do not necessarily state or reflect those of the United States Government or any agency thereof.
\end{abstract}


ORNL/TM-2020/1582

CRADA/NFE-18-07415

Materials Science \& Technology Division

Advanced Manufacturing Office

\title{
Feedstock Modification for Enhanced Additive Alloys
}

\author{
Alex Plotkowski \\ Ryan Dehoff \\ Fred List \\ Keith Carver
}

Date Published:

June 2020

\author{
Prepared by \\ OAK RIDGE NATIONAL LABORATORY \\ Oak Ridge, Tennessee 37831-6283 \\ managed by \\ UT-BATTELLE, LLC \\ for the \\ US DEPARTMENT OF ENERGY \\ under contract DE-AC05-00OR22725
}

Approved For Public Release 



\section{CONTENTS}

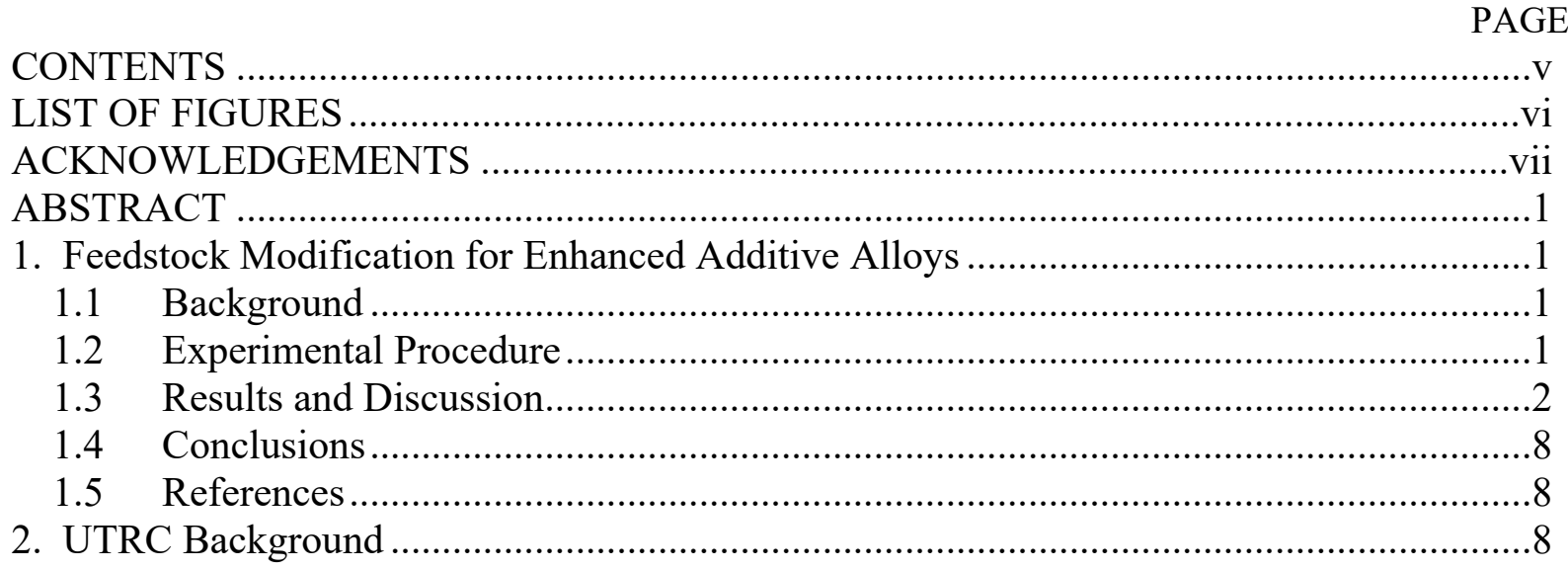




\section{LIST OF FIGURES}

Figure 1: SEM micrographs comparing powder characteristics between IN625 and ODS IN625.

Figure 2: SEM micrographs of ODS-IN625 powder after recycling.

Figure 3: Photographs of completed design of experiments builds of IN625 and ODS-IN625.

Table 1: Summary of Renishaw AM250 process parameters used to produce test coupons ....3 Figure 4: Photograph of completed IN625 test coupons and (right) example of witness marks produced by unexpected pause in process, but formed outside of the gage section.................4

Figure 5: Inverse pole figure maps of the post-processed IN625 and ODS IN625 samples.....5 Figure 6: Number and area weighted grain statistics from the IN625 and ODS IN625 additively manufactured samples (data includes twins).

Figure 7: Example tensile curves for IN625 and ODS IN625 AM samples in the HIP condition. The plot is truncated at 5\% elongation to highlight the differences in yield behavior.

Table 2: Summary of room temperature tensile properties for IN625 and ODS IN625 samples in the HIP condition compared to wrought properties (wrought data taken from Special

Metals datasheet:

https://www.specialmetals.com/assets/smc/documents/alloys/inconel/inconel-alloy-625.pdf) 6 Table 3: Summary of tensile properties at $1400^{\circ} \mathrm{F}$ compared to wrought properties (wrought properties taken from Special Metals and ATI datasheets:

https://www.specialmetals.com/assets/smc/documents/alloys/inconel/inconel-alloy-625.pdf) 6 Figure 8: Stress rupture data for additively manufacturing IN625 and ODS IN625 compared to wrought data (wrought data taken from Special Metals data sheet:

https://www.specialmetals.com/assets/smc/documents/alloys/inconel/inconel-alloy-625.pdf) 7

Table 4: Summary of measured stress rupture behavior.

Figure 9: Weight gain as a function of time from corrosion testing of the additively

manufactured IN625 and ODS-IN625 materials. 


\section{ACKNOWLEDGEMENTS}

This CRADA NFE-18-07415 was conducted as a Technical Collaboration project within the Oak Ridge National Laboratory (ORNL) Manufacturing Demonstration Facility (MDF) sponsored by the US Department of Energy Advanced Manufacturing Office (CPS Agreement Number 24761).

Opportunities for MDF technical collaborations are listed in the announcement "Manufacturing Demonstration Facility Technology Collaborations for US Manufacturers in Advanced

Manufacturing and Materials Technologies" posted at http:/web.ornl.gov/sci/manufacturing/docs/FBO-ORNL-MDF-2013-2.pdf. The goal of technical collaborations is to engage industry partners to participate in short-term, collaborative projects within the Manufacturing Demonstration Facility (MDF) to assess applicability and of new energy efficient manufacturing technologies. Research sponsored by the U.S. Department of Energy, Office of Energy Efficiency and Renewable Energy, Advanced Manufacturing Office, under contract DE-AC0500OR22725 with UT-Battelle, LLC. 


\begin{abstract}
This project investigated the use of $\mathrm{Y}_{2} \mathrm{O}_{3}$ nanoparticles to enhance IN625 feedstock for metal additive manufacturing. The oxide nanoparticles are adhered to the outer surface of the prealloyed IN625 powder feedstock, and serve to form an oxide dispersion strengthened (ODS) material in situ during processing. The conventional and enhanced feedstocks were processed using a laser powder bed fusion additive manufacturing (AM) system. The properties of the AM materials were characterized at elevated temperatures and compared to conventional wrought material. The addition of the $\mathrm{Y}_{2} \mathrm{O}_{3}$ nanoparticles improved the yield strength, stress rupture, and corrosion properties of the AM material, and compared more favorably with conventional wrought IN625. This research will enable future adoption of additively manufactured ODS-IN625 components with superior properties to current printed IN625 material.
\end{abstract}

\title{
1. FEEDSTOCK MODIFICATION FOR ENHANCED ADDITIVE ALLOYS
}

This phase 1 technical collaboration project (MDF-TC-2019-154) began on December 6, 2019 and concluded on June 30, 2020. The collaboration partner, United Technologies Research Center, is a medium business. This project investigated the influence of the use of $\mathrm{Y}_{2} \mathrm{O}_{3}$ nano-particles to enhance IN625 feedstock for metal additive manufacturing, and found that the ODS material improved yield strength, stress rupture life, and corrosion resistance at elevated temperatures.

\subsection{BACKGROUND}

Modification of pre-alloyed powder feedstock for AM through the addition of nano-scale secondary phases has been shown to be an effective approach to achieving desirable microstructures and properties, such as to avoid hot-tearing in crack-prone Al alloys [1]. However, the same approach offers opportunities in other alloys systems. In particular, additional of nano-scale particles to common AM powder feedstocks may be an approach to achieve in situ formation of oxide dispersion strengthened (ODS) steels [2,3] or Ni-based superalloys [4], which are used via conventional processing due to their improved hightemperature properties, particularly strength and corrosion resistance $[5,6]$. In particular, oxidation behavior of IN625 has been shown to benefit from incorporation of nanoscale yttria [7]. However, relatively little data is available on the influence of ODS modification of IN625 on high temperature mechanical properties relative to AM of conventional IN625 and wrought properties. The purpose of this work is to additively manufacture nano-ODS modified IN625 feedstock and to characterize key microstructural features and associated properties.

\subsection{EXPERIMENTAL PROCEDURE}

UTRC prepared powder feedstock for IN625 and ODS-IN625, which included 1.5 vol.\% nano-scale particles of yttria $\left(\mathrm{Y}_{2} \mathrm{O}_{3}\right)$. The powders were suitably sized for laser powder bed fusion (LPBF) additive manufacturing. LPBF was performed using a Renishaw AM250 system at ORNL's Manufacturing Demonstration Facility (MDF). A central composite design of experiments was used for both materials to identify a suitable process window for 
each. Using the selected process conditions, samples were manufactured for quasi-static tensile, stress rupture, and corrosion testing. These samples were stress relieved/solution treated and HIP'd prior to testing to eliminate variation due to as-fabricated build defects. In addition to these tests, material was characterized using scanning electron microscopy and electron back-scatter diffraction.

\subsection{RESULTS AND DISCUSSION}

Scanning electron micrographs of the as-received powder is shown in Figure 1. Powder particles for both the IN625 and ODS-IN625 material was largely spherical. The nano-scale $\mathrm{Y}_{2} \mathrm{O}_{3}$ particles are visible on the surface of the ODS-IN625 powder. The $\mathrm{Y}_{2} \mathrm{O}_{3}$ particles are mostly well dispersed, but some large agglomerates were also observed.
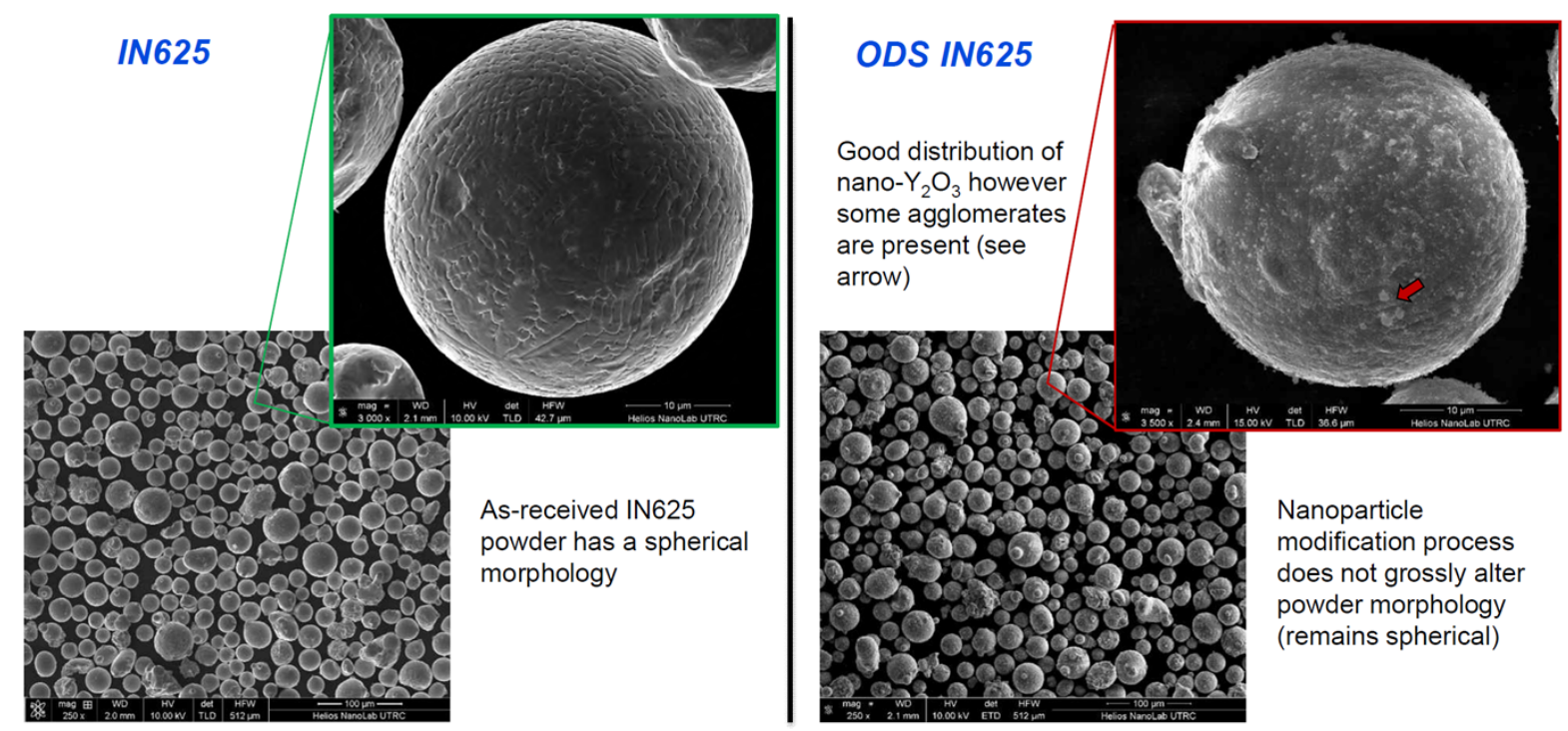

Figure 1: SEM micrographs comparing powder characteristics between IN625 and ODS IN625.

The ODS-IN625 was also characterized following powder re-use as shown by the SEM micrographs in Figure 2. Although some additional agglomeration of $\mathrm{Y}_{2} \mathrm{O}_{3}$ may have occurred, the nano-particles remained adhered to the surface of the powder particles. This result is encouraging for recyclability, suggesting that the powder may be reused multiple times without losing the ODS effect of the nano-particles. 


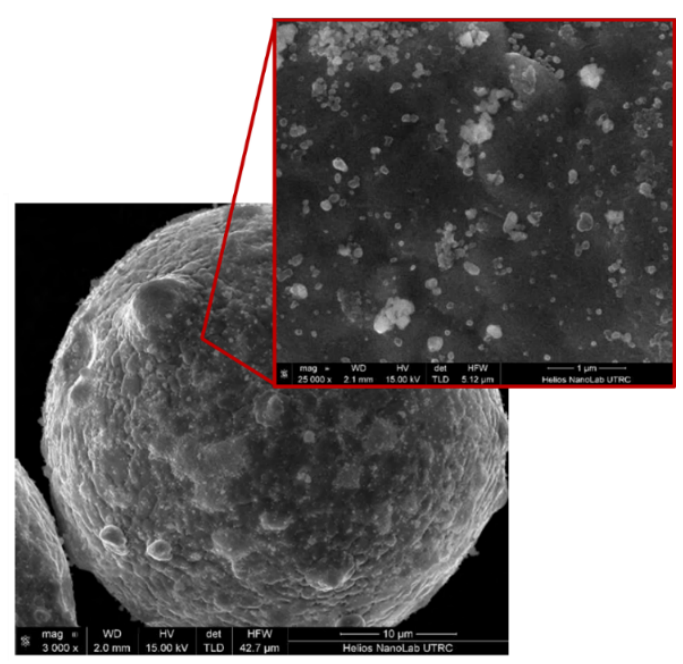

Figure 2: SEM micrographs of ODS-IN625 powder after recycling.

Images of the design of experiments builds for each powder are shown in Figure 3. The central composite design includes 11 replicates of the central parameter set to assess process repeatability, with 14 additional parameter sets test varying in point spacing, exposure time, and hatch spacing. Figure 3 highlights two parameter sets that skewed towards higher energy density, showing that the ODS material tolerated the increased energy input better than the standard IN625 material, which is consistent with previously reported results [4]. Based on these results, a common parameter set was selected to build test coupons for both materials. These process parameters are summarized in Table 1.
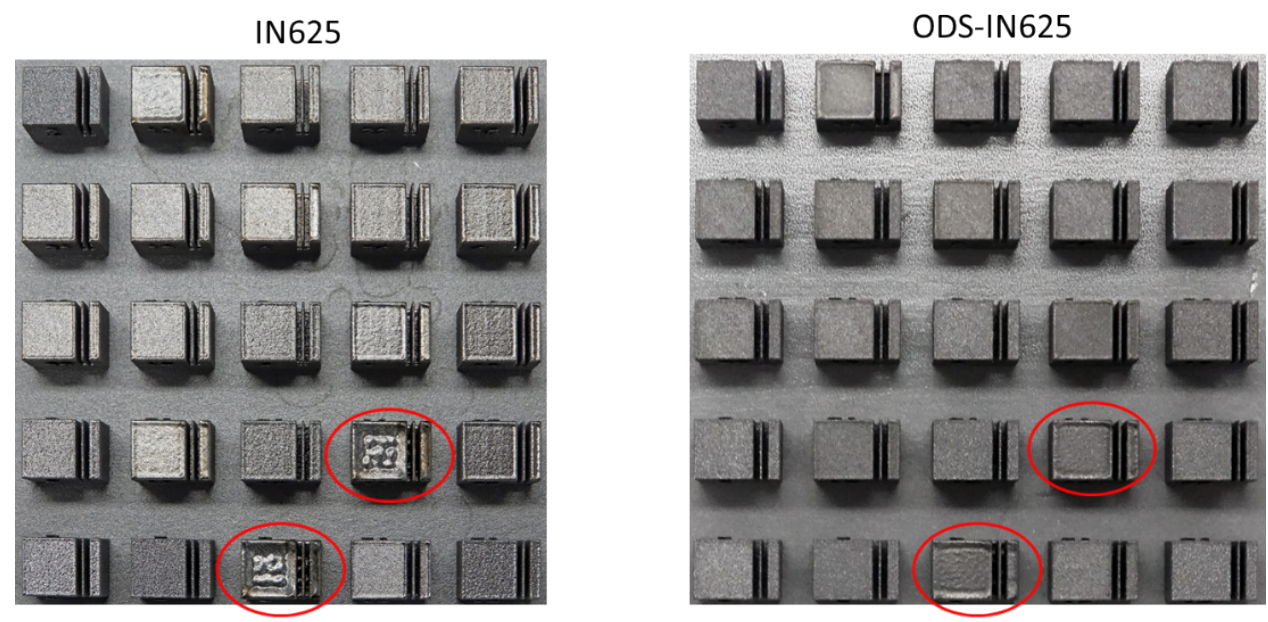

Figure 3: Photographs of completed design of experiments builds of IN625 and ODS-IN625.

Table 1: Summary of Renishaw AM250 process parameters used to produce test coupons

\begin{tabular}{|l|l|}
\hline Parameter & Value \\
\hline Power $(\mathrm{W})$ & 200 \\
\hline Point spacing $(\mu \mathrm{m})$ & 80 \\
\hline Hatch spacing $(\mu \mathrm{m})$ & 100 \\
\hline Exposure time $(\mu \mathrm{s})$ & 135 \\
\hline
\end{tabular}


Using these process conditions, test coupons were manufactured from each material for quasi-static, stress rupture, and corrosion testing. An image of the IN625 test coupon build is shown in Figure 4. In this case, due to the limited amount of powder, the build was paused to refill the powder hopper and then restarted. This procedure left a witness mark that was visible in the surface of the samples. However, this interruption occurred outside of the gage section of all of the samples, and did not influence subsequent testing. A similar build was produced from the ODS-IN625 material for comparison.
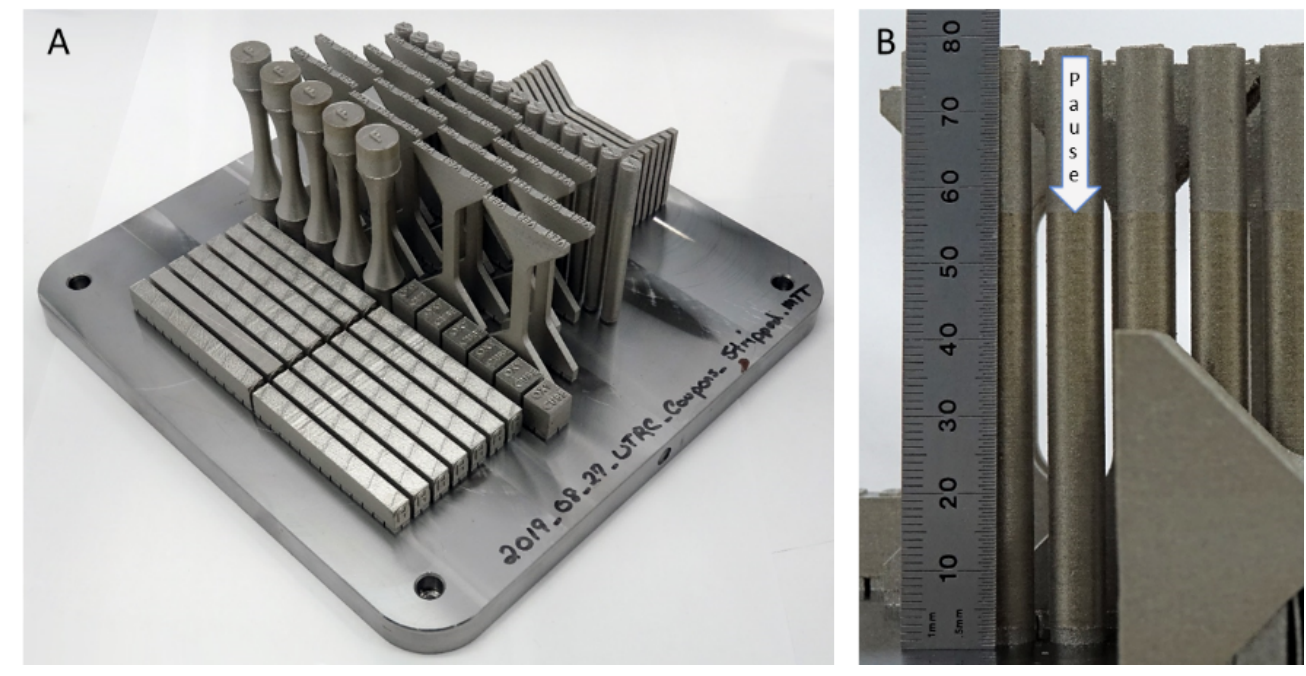

Figure 4: Photograph of completed IN625 test coupons and (right) example of witness marks produced by unexpected pause in process, but formed outside of the gage section.

Stitched scanning electron micrographs of the post-processed (heat treatment and HIP) specimens is shown for both IN625 and ODS-IN625 material in Figure 5. The ODS-IN625 sample shows $\mathrm{Y}_{2} \mathrm{O}_{3}$ agglomerates incorporated into the microstructure that are not found in the IN625 sample. In addition, higher magnification micrographs show individual nano-scale $\mathrm{Y}_{2} \mathrm{O}_{3}$ particles (Figure 6). From this data alone, it is not possible to draw specific conclusions regarding the evolution of $\mathrm{Y} 2 \mathrm{O} 3$ particles during AM processing.

\section{IN625}

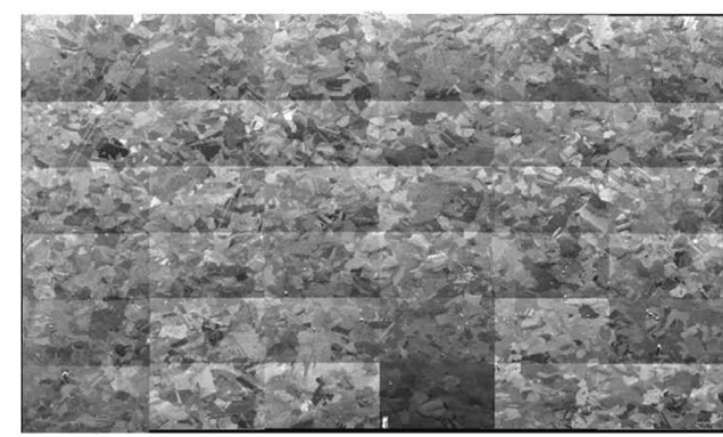

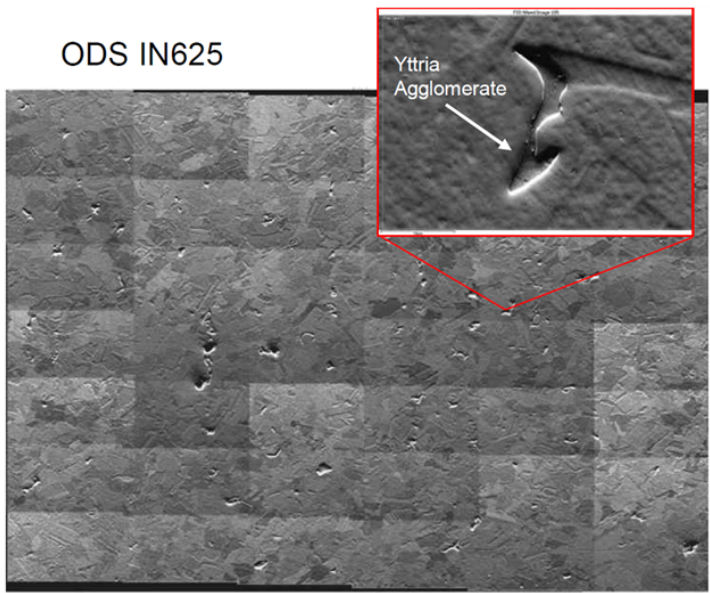

Figure 5: Stitched scanning electron micrographs comparing the IN625 and ODS-IN625 AM samples. The ODS-IN625 sample shows evidence of Yttria agglomerates incorporated into the microstructure. 

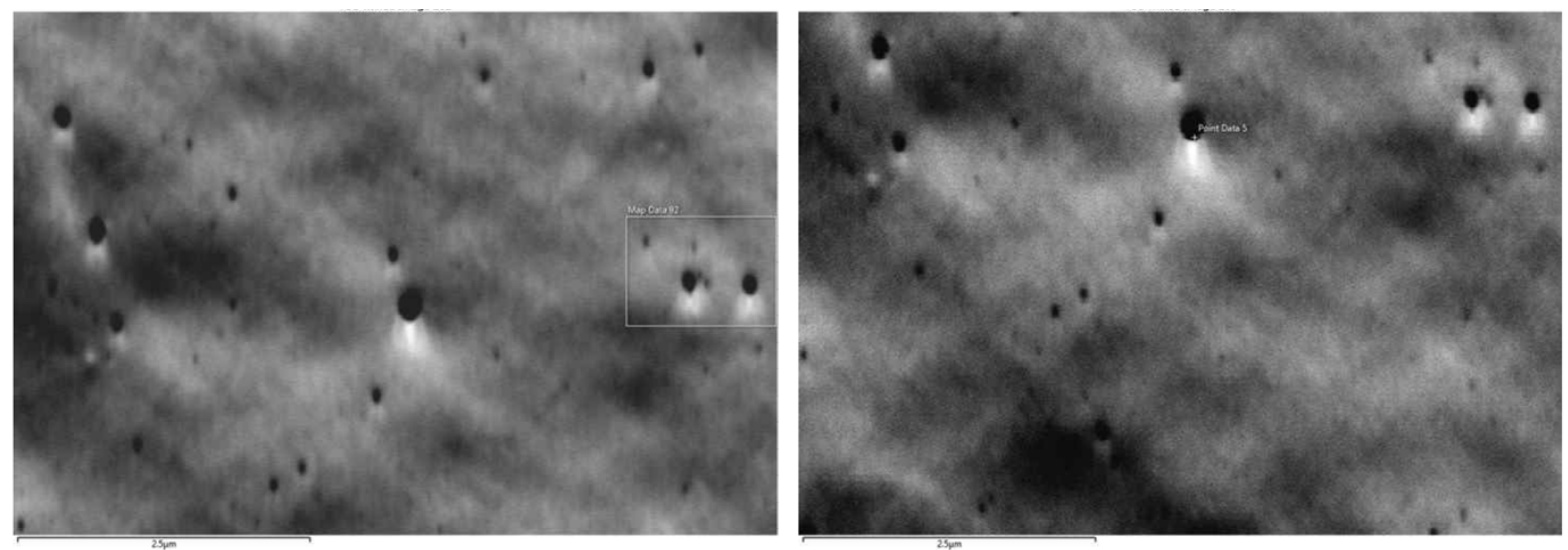

Figure 6: Scanning electron micrographs showing nanoscale Y2O3 particles in the ODS-IN625 microstructure. Micrographs taken from the $x-y$ plane.

Following post-processing (heat treatment and HIP) the grain structure of two representative components, one from each material, was characterized using electron backscatter diffraction (EBSD). Inverse pole figure maps of the resulting grain structures are shown in Figure 7. Although previous work on ODS of Ni-superalloys suggests that incorporation of nano-scale oxides can have a significant effect on recrystallized grains structures [5], little difference between the IN625 and ODS-IN625 material was observed here. Number and area weighted grain size distributions are shown for both in Figure 8. The ODS-IN625 material shows a slightly larger average grain size, but the differences are small.

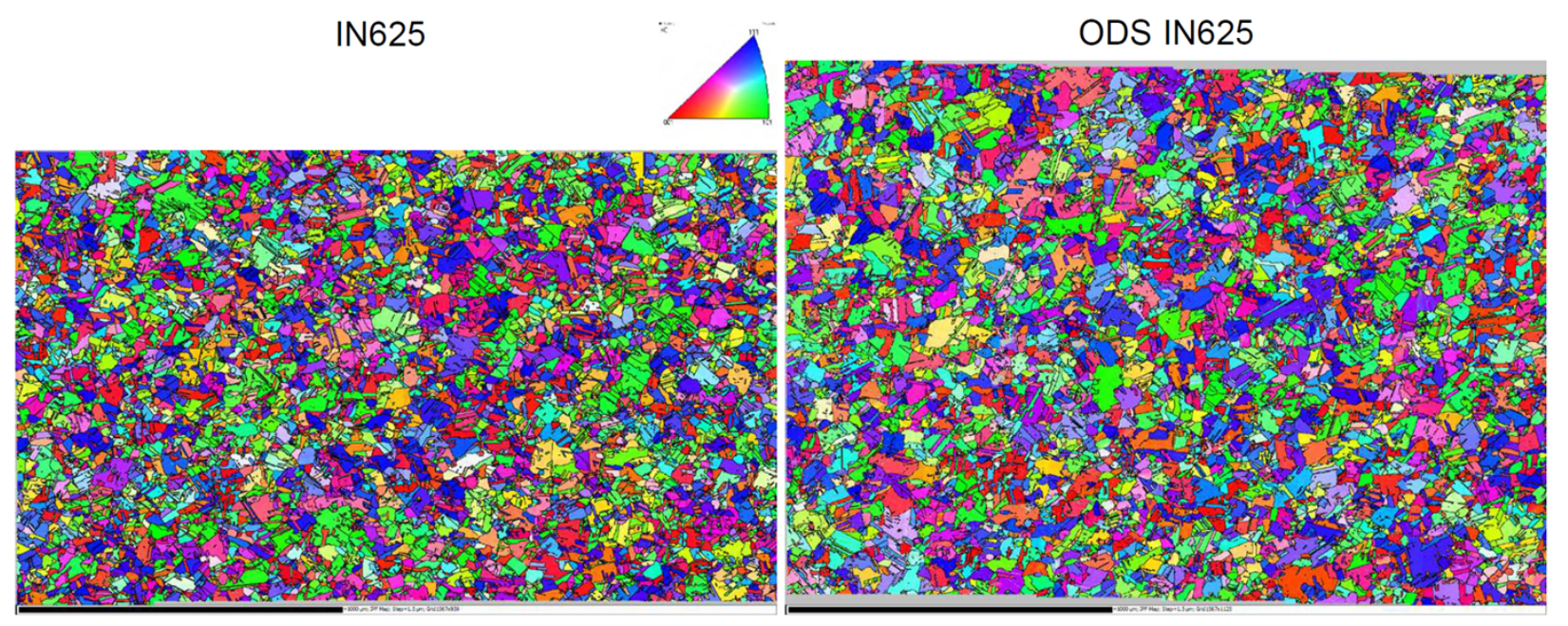

Figure 7: Inverse pole figure maps of the post-processed IN625 and ODS IN625 samples. 
IN625
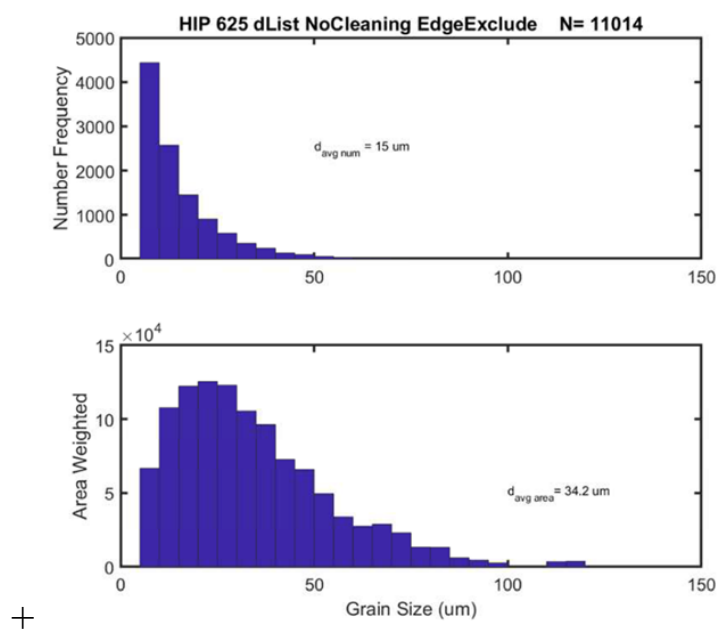

ODS IN625
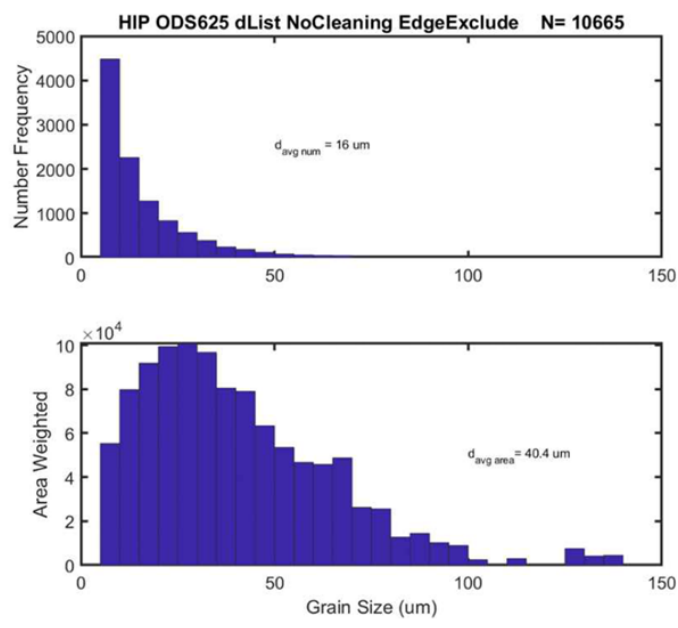

Figure 8: Number and area weighted grain statistics from the IN625 and ODS IN625 additively manufactured samples (data includes twins).

The quasi-static tensile properties for both materials was measured at room temperature and at $1400^{\circ} \mathrm{F}$. Representative tensile curves are shown in Figure 9, and tensile properties are summarized in Table 2 and Table 3. At both temperatures, the addition of the nano-scale $\mathrm{Y}_{2} \mathrm{O}_{3}$ particles increased the yield strength, but did not strongly affect the ultimate tensile strength. At room temperature, the ODS material had a slight decrease in elongation. At $1400^{\circ} \mathrm{F}$, the elongation was slightly higher in the horizontal direction, but lower in the vertical direction. At room temperature, the properties for both alloys fall within the range expected of wrought IN625. At $1400^{\circ} \mathrm{F}$ however, the yield strength and UTS are slightly lower than wrought material, and the elongation is significantly lower. This high-temperature embrittlement is consistent with previous studies which have attributed this effect to the formation of grain boundary carbides [8,9]. Note that the experimental error in determining modulus from these tensile curves is high, so no significant conclusions may be drawn from this data. 


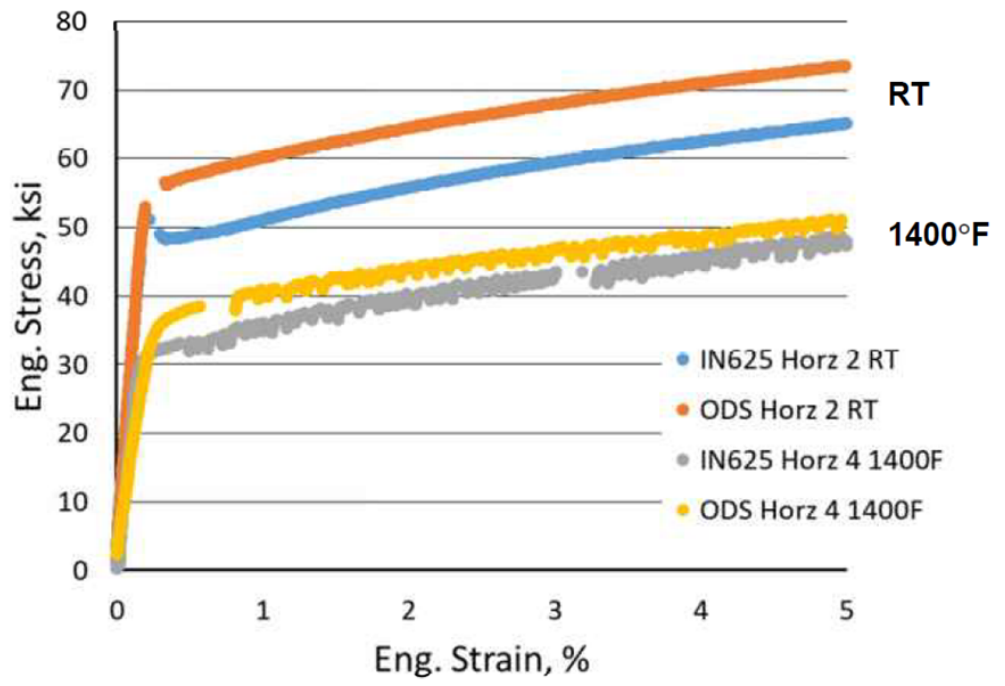

Figure 9: Example tensile curves for IN625 and ODS IN625 AM samples in the HIP condition. The plot is truncated at 5\% elongation to highlight the differences in yield behavior.

Table 2: Summary of room temperature tensile properties for IN625 and ODS IN625 samples in the HIP condition compared to wrought properties (wrought data taken from Special Metals datasheet:

https://www.specialmetals.com/assets/smc/documents/alloys/inconel/inconel-alloy-625.pdf)

\begin{tabular}{|l|c|c|c|c|c|c|}
\hline \multicolumn{2}{|l|}{ Sample } & & Modulus (Msi) & $\mathbf{0 . 2 \%}$ Yield (ksi) & UTS (ksi) & Elong. (\%) \\
\hline \multirow{3}{*}{ IN625 } & \multirow{3}{*}{ Horz } & 1 & 24.6 & 51 & 114 & 57.65 \\
\cline { 2 - 7 } & \multirow{2}{*}{ Vert } & 2 & 27 & 48.5 & 108.6 & 58.75 \\
\cline { 3 - 7 } & & 2 & - & 50 & 111.8 & 62.65 \\
\hline \multirow{3}{*}{$\begin{array}{l}\text { ODS } \\
\text { IN625 }\end{array}$} & \multirow{2}{*}{ Horz } & 1 & 35.2 & 50 & 111.7 & 60.9 \\
\cline { 2 - 7 } & \multirow{2}{*}{ Vert } & 2 & 32.4 & 56.9 & 110.7 & 43.5 \\
\cline { 2 - 7 } & & 2 & 31.8 & 55.5 & 110.1 & 44.75 \\
\cline { 2 - 7 } & & 33.7 & 56 & 109.8 & 49.55 \\
\hline \multicolumn{2}{|l}{ Wrought IN625 } & 29.9 & $40-60$ & $105-130$ & 44.4 \\
\hline
\end{tabular}

Table 3: Summary of tensile properties at $1400^{\circ} \mathrm{F}$ compared to wrought properties (wrought properties taken from Special Metals and ATI datasheets:

https://www.specialmetals.com/assets/smc/documents/alloys/inconel/inconel-alloy-625.pdf)

\begin{tabular}{|l|l|l|c|c|c|c|}
\hline \multicolumn{2}{|l|}{ Sample } & Modulus (Msi) & $\mathbf{0 . 2 \%}$ Yield (ksi) & UTS (ksi) & Elong. (\%) \\
\hline \multirow{2}{*}{ IN625 } & Horz & 4 & 22.1 & 32.5 & 59.37 & 34.6 \\
\cline { 2 - 7 } & Vert & 4 & 17.2 & 31.2 & 60.2 & 39.65 \\
\hline \multirow{2}{*}{$\begin{array}{l}\text { ODS } \\
\text { IN625 }\end{array}$} & Horz & 4 & 14 & 38 & 62.4 & 41.9 \\
\cline { 2 - 7 } & Vert & 8 & 18.1 & 36.3 & 58.6 & 33.05 \\
\hline \multicolumn{2}{|l}{ Wrought IN625 } & 22.8 & 40 & 77 & 90 \\
\hline
\end{tabular}

The stress rupture behavior is shown in Figure 10 at 1400 and $1500^{\circ} \mathrm{F}$ as compared to wrought material, and summarized in Table 4. The AM IN625 material significant underperformance wrought IN625 at both temperatures. The ODS-IN625 however, show significant improvement, with similar performance to wrought at $1400^{\circ} \mathrm{F}$, and a slight decrease in rupture life relative to wrought at $1500^{\circ} \mathrm{F}$. 


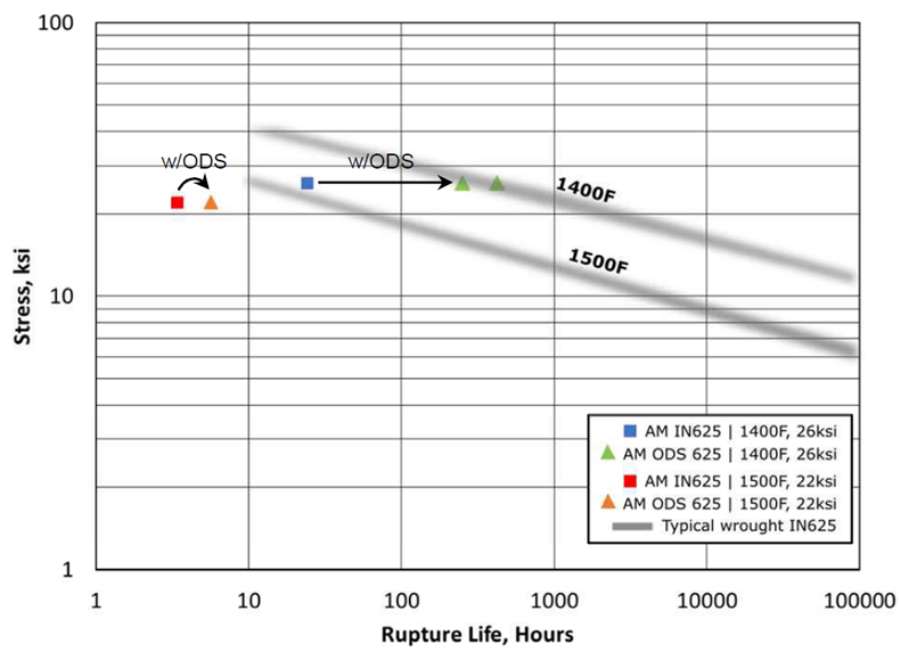

Figure 10: Stress rupture data for additively manufacturing IN625 and ODS IN625 compared to wrought data (wrought data taken from Special Metals data sheet:

https://www.specialmetals.com/assets/smc/documents/alloys/inconel/inconel-alloy-625.pdf)

Table 4: Summary of measured stress rupture behavior.

\begin{tabular}{|r|c|c|c|}
\hline Coupon & ${\text { Temp. }\left({ }^{\circ} \mathbf{F}\right)}$ & Stress (ksi) & Time to Fail (hr) \\
\hline \multirow{2}{*}{ IN625 } & 1400 & 26 & 26.5 \\
\cline { 2 - 4 } & 1500 & 22 & 3.4 \\
\hline \multirow{2}{*}{ ODS IN625 } & 1400 & 26 & $250-420$ \\
\cline { 2 - 4 } & 1500 & 22 & 537 \\
\hline
\end{tabular}

The corrosion behavior of the two AM materials is shown in Figure 11. Relative to the standard AM IN625 alloys, the ODS-IN625 shows a significant improvement in corrosion resistance. This finding is consistent with previous reports of improved corrosion resistance for ODS modified Ni-based superalloys [7].

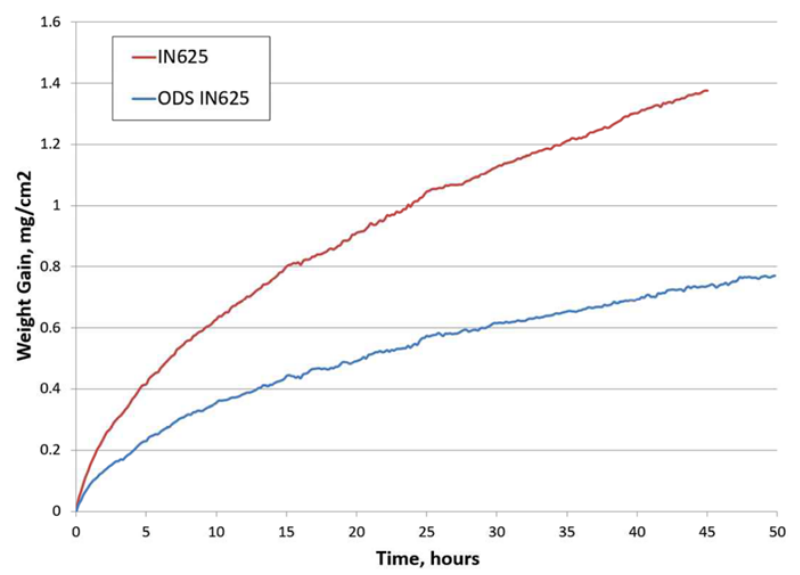

Figure 11: Weight gain as a function of time from corrosion testing of the additively manufactured IN625 and ODS-IN625 materials. 


\subsection{CONCLUSIONS}

This study investigated the use of nano-scale $\mathrm{Y}_{2} \mathrm{O}_{3}$ particles to enhance IN625 powder feedstock for metal additive manufacturing. Appropriate IN625 powders were manufactured with and without the $\mathrm{Y}_{2} \mathrm{O}_{3}$ particles. A Renishaw AM250 laser powder bed fusion system was used to manufacturing test coupons for determining quasi-static tensile, stress rupture, and corrosion properties at elevated temperatures. The ODS-IN625 material was found to exhibit improved yield strength, stress rupture life, and corrosion resistance than the unmodified material. The ODS-IN625 compared more favorably to wrought IN625 than unmodified IN625 AM components.

\subsection{REFERENCES}

[1] Martin JH, Yahata BD, Hundley JM, Mayer JA, Schaedler TA, Pollock TM. 3D printing of highstrength aluminium alloys. Nature 2017;549:365-9. https://doi.org/10.1038/nature23894.

[2] Walker JC, Berggreen KM, Jones AR, Sutcliffe CJ. Fabrication of Fe-Cr-Al oxide dispersion strengthened pm2000 alloy using selective laser melting. Adv Eng Mater 2009;11:541-6. https://doi.org/10.1002/adem.200800407.

[3] Boegelein T, Dryepondt SN, Pandey A, Dawson K, Tatlock GJ. Mechanical response and deformation mechanisms of ferritic oxide dispersion strengthened steel structures produced by selective laser melting. Acta Mater 2015;87:201-15. https://doi.org/10.1016/j.actamat.2014.12.047.

[4] Spierings AB, Bauer T, Dawson K, Colella A, Wegener K. Processing ODS Modified IN625 Using Selective Laser Melting. SFF 2015, 2015.

[5] Capdevila C, Bhadeshia HKDH. Manufacturing and microstructural evolution of mechanuically alloyed oxide dispersion strengthened superalloys. Adv Eng Mater 2001;3:647-56. https://doi.org/10.1002/1527-2648(200109)3:9<647::AID-ADEM647>3.0.CO;2-4.

[6] Singer RF, Arzt E. Structure, Processing, and Properties of ODS Superalloys. High Temp. Alloy. gas turbines other Appl., 1986, p. 97-126.

[7] Arnold K, Tatlock G, Kenel C, Colella A, Matteazzi P. High temperature isothermal oxidation behaviour of an oxide dispersion strengthened derivative of IN625. Mater High Temp 2018;35:141-50. https://doi.org/10.1080/09603409.2017.1393145.

[8] Hu XA, Zhao G Le, Liu FC, Liu WX. Microstructure and mechanical behavior of Inconel 625 alloy processed by selective laser melting at high temperature up to $1000^{\circ} \mathrm{C}$. Rare Met 2019. https://doi.org/10.1007/s12598-019-01321-3.

[9] Kreitcberg A, Brailovski V, Turenne S. Elevated temperature mechanical behavior of IN625 alloy processed by laser powder-bed fusion. Mater Sci Eng A 2017;700:540-53. https://doi.org/10.1016/j.msea.2017.06.045.

\section{UTRC BACKGROUND}

UTRC is the corporate research center for United Technologies Corporation and is headquartered in a 420,000 $\mathrm{ft}^{2}$ complex in East Hartford, CT. UTRC plays a key role as the corporation's innovation engine, focusing on advanced technologies for its aerospace (Pratt \& Whitney and UTC Aerospace Systems) and industrial (Otis and UTC Climate Controls, and Security) business units. UTRC performs basic, applied and exploratory research in a broad spectrum of technologies including chemical sciences, fluid mechanics, electronics, materials and structures, information technology, and systems technology. By an amendment to its certificate of incorporation, dated April 3, 2020, United Technologies Corporation, a Delaware corporation, has changed its name to Raytheon Technologies Corporation. Therefore, going forward, "United Technologies Corporation, acting here through 
United Technologies Research Center, its unincorporated operating unit" will contract as "Raytheon Technologies Corporation, acting here through Raytheon Technologies Research Center, its unincorporated operating unit", with an office at 411 Silver Lane, East Hartford, Connecticut 06118. 